\title{
Ano-vesical reflex: role in inducing micturition in paraplegic patients
}

\author{
A Shafik MD \\ Professor and Chairman, Department of Surgery and Research, Faculty of Medicine, \\ Cairo University, Cairo, Egypt.
}

The reflex relationship between the anal canal and the urinary bladder was investigated in 14 normal volunteers and in seven patients with spinal cord injury of more than 2 years duration. The latter induced urination by dilating the anal canal with the finger. The vesical pressure was measured by a balloon-tipped catheter introduced into the urinary bladder which was filled with $100 \mathrm{ml}$ saline. The anal canal was inflated with a balloon catheter filled with $2 \mathrm{ml}$ air; inflation was increased in increments of $2 \mathrm{ml}$ up to $10 \mathrm{ml}$. The vesical pressure in response to both slow and rapid anal distension was recorded. The external and internal anal sphincters were blocked separately and the test was repeated. Rapid anal inflation elevated the vesical pressure. The greater the anal inflation, the higher the vesical pressure. Slow anal distension induced insignificant vesical pressure changes $(p>0.05)$. Rapid anal distension with internal sphincter block induced insignificant vesical pressure changes $(p>0.05)$ while the vesical pressure showed a significant increase with external sphincter block. In paraplegic subjects, the vesical pressure increased on rapid anal distension with $6 \mathrm{ml}$ air but did not further increase with greater distension. Vesical pressure increase was recorded after external sphincter block but there was an insignificant change after internal sphincter paralysis. The aforementioned results were reproducible. The study demonstrates that rapid anal distension was accompanied by an increase in vesical pressure; this reflex relation is called 'ano-vesical reflex'. It appears that in paraplegic patients, who induce voiding by finger anal dilatation, micturition is initiated through this reflex.

Keywords: rectum; anal canal; micturition; defecation; ano-vesical reflex; urinary bladder; paraplegia.

\section{Introduction}

The mechanism of evacuation, whether of faeces or urine is intricate. It is the result of detrusor contraction and outlet relaxation. $^{1-3}$ Both elements, the detrusor and outlet, maintain a sound cycle of storage and evacuation which is controlled by a group of reflex and voluntary actions. ${ }^{3-8}$

It was observed that patients with a paralysed urinary bladder from a spinal cord injury can initiate the micturition reflex by introducing a finger into the anal canal. It was suggested that a reflex relation exists between the anal canal and the urinary bladder. This communication aims at investigating such a hypothesis. The paper is

Correspondence: Ahmed Shafik, MD, 2 Talaat Harb Street, Cairo, Egypt. not intended to describe what happens to micturition during anal distension but rather aims at depicting what happens to the intravesical pressure on anal distension.

\section{Subjects and methods}

\section{Normal subjects}

The study comprised 14 healthy volunteers. Ten were men and four women. Ages ranged from 24 to 58 years (mean SD $36.4 \pm 12.2$ years). They had no anorectal or urinary complaint at the time of presentation or in the past. Physical examination, including neurological and anorectal, was normal; as were stool frequency, barium enema examination and colonoscopy. Urinalysis, plain $\mathrm{x}$-rays for the urinary tract and intravenous pyelography were also 
normal. The volunteers signed an informed consent before entering the study.

\section{Paraplegic subjects}

Seven patients with the clinical manifestations of complete spinal cord transection were studied. Clinical data are shown in Table I. Before their cord injury they had no urinary or anorectal trouble. Their injury was of more than 2 years duration, and no patient was in a state of spinal shock. None had spontaneous defecation or urination. They defecated with glycerine suppositories or enemas. Urination was initiated by dilating the anal canal with the finger. Urodynamic investigations showed detrusor hyperreflexia. The anal reflex was present indicating that none of the patients had a conus medullary injury.

\section{Methods}

With the subject lying supine, a Nelaton catheter no. $10 \mathrm{~F}$ with a balloon at its tip

Table I Clinical data of the seven patients with spinal cord injury

\begin{tabular}{ccccc}
\hline $\begin{array}{l}\text { Pt. } \\
\text { no. }\end{array}$ & $\begin{array}{c}\text { Age } \\
\text { (years) }\end{array}$ & Sex & $\begin{array}{c}\text { Duration } \\
\text { (years) }\end{array}$ & $\begin{array}{c}\text { Segmental level } \\
\text { of cord lesion }\end{array}$ \\
\hline 1 & 23 & M & 3 & T4 \\
2 & 46 & $\mathrm{~F}$ & 5 & T4 \\
3 & 35 & M & 4 & T5 \\
4 & 44 & M & 4 & T6 \\
5 & 38 & F & 3 & T6 \\
6 & 40 & M & 6 & T5 \\
7 & 55 & M & 5 & T5 \\
\hline
\end{tabular}

was introduced per urethram into the urinary bladder filled with $100 \mathrm{ml}$ saline. The catheter was connected to a strain gauge pressure transducer (Statham 230b, Oxnard, California). Another balloontipped $10 \mathrm{~F}$ catheter was introduced into the anal canal so that the balloon lay $2-3 \mathrm{~cm}$ from the anal orifice. The anal balloon was inflated with $2 \mathrm{ml}$ air, and the vesical pressure was recorded. Balloon inflation was increased in increments of $2 \mathrm{ml}$ up to $10 \mathrm{ml}$. It was performed at two rates: rapid and slow. The inflated balloon in the anal canal simulates the dilating and stimulating effect induced by the finger.

To demonstrate whether the effect of anal canal inflation is due to external or internal anal sphincter stretch, each was paralysed separately and the experiment was repeated. The external anal sphincter was paralysed by a bilateral pudendal nerve block, and the internal sphincter by phentolamine administration.

The aforementioned procedures were repeated at least twice to assure reproducibility.

\section{Statistical analyses}

The results were analysed statistically using Student's $t$ test.

\section{Results}

\section{Normal subjects}

The urinary bladder filled with $100 \mathrm{ml}$ saline recorded a pressure varying from 10 to $16 \mathrm{~cm} \mathrm{H}_{2} \mathrm{O}$ (mean SD $12.7 \pm 1.2 \mathrm{~cm} \mathrm{H}_{2} \mathrm{O}$ ).

Table II The vesical pressure at the different volumes of rapid anal inflation in 14 healthy volunteers and seven patients with spinal cord injury

\begin{tabular}{ccccc}
\hline \multirow{2}{*}{$\begin{array}{c}\text { Volume of anal inflation } \\
(\mathrm{ml})\end{array}$} & \multicolumn{4}{c}{ Vesical pressure $\left(\mathrm{cm} \mathrm{H}_{2} \mathrm{O}\right)^{\mathrm{a}}$} \\
\cline { 2 - 5 } & Range & $\begin{array}{c}\text { Normal } \\
\text { Mean }\end{array}$ & Range & Paraplegics \\
& & & Mean \\
\hline 0 & $10-16$ & $12.7 \pm 1.2$ & $12-19$ & $13.6 \pm 2.1$ \\
2 & $22-33$ & $28.2 \pm 6.4^{\mathrm{b}}$ & $14-21$ & $14.9 \pm 3.2^{\mathrm{c}}$ \\
6 & $30-46$ & $36.4 \pm 8.9^{\mathrm{d}}$ & $26-42$ & $33.2 \pm 7.6^{\mathrm{d}}$ \\
10 & $38-65$ & $49.3 \pm 11.6^{\mathrm{d}}$ & $25-40$ & $34.6 \pm 8.5^{\mathrm{d}}$ \\
\hline
\end{tabular}

${ }^{a}$ Values are given as mean \pm standard deviation.

${ }^{\mathrm{b}} p<0.01 ;{ }^{\mathrm{c}} p>0.05 ;{ }^{\mathrm{d}} p<0.001$. 
Upon rapid anal inflation with the balloon, the vesical pressure increased. The greater the anal inflation, the higher the vesical pressure (Table II). Thus, at anal inflation with $2 \mathrm{ml}$ air, the urinary bladder recorded a mean pressure of $28.2 \pm 6.4 \mathrm{SD} \mathrm{cm} \mathrm{H}_{2} \mathrm{O}$, and at anal inflation with $10 \mathrm{ml}$, it recorded a mean pressure of $49.3 \pm 11.6 \mathrm{~cm} \mathrm{H}_{2} \mathrm{O}$. Slow anal inflation did not induce significant vesical pressure changes.

When the internal anal sphincter tone was inhibited by phentolamine administration, anal inflation with up to $10 \mathrm{ml}$ air did not evoke a vesical response; the vesical pressure did not show significant changes $(p>0.05)$. On the other hand, when the external anal sphincter was paralysed, anal inflation showed a vesical pressure increase, which differed insignificantly from the one effected by anal inflation with the unparalysed external sphincter $(p>0.05)$.

The above results were reproducible in the individual subject.

\section{Paraplegic subjects}

The pressure in the urinary bladder containing $100 \mathrm{ml}$ saline varied from 12 to $19 \mathrm{~cm}$ $\mathrm{H}_{2} \mathrm{O}$ (mean SD $13.6 \pm 2.1 \mathrm{~cm} \mathrm{H}_{2} \mathrm{O}$ ) (Table II). The vesical pressure did not show a significant increase with slow or with rapid anal inflation at volumes of 2 and $4 \mathrm{ml}$ air $(p>0.05)$ (Table II). It increased upon rapid anal inflation with $6 \mathrm{ml}$ air, but did not show a significant increase with larger volumes of anal inflation $(p>0.05)$ (Table II). Slow and gradual anal inflation induced insignificant vesical pressure changes $(p>0.05)$.

Anal inflation after internal anal sphincter inhibition with phentolamine administration showed insignificant vesical pressure changes $(p>0.05)$. Meanwhile it induced a vesical pressure increase both before and after external anal sphincter paralysis, with an insignificant difference between the two $(p>0.05)$.

\section{Discussion}

The present results show that, in normal subjects, rapid anal inflation by the balloon which simulates anal dilatation by the finger was accompanied with increased vesical pressure. This vesical pressure increase on anal inflation occurred with external sphincter paralysis, but not with inhibition of the internal sphincter tone. This indicates that the vesical pressure increase is an effect of internal not of external sphincter dilatation. The reflex relationship between the internal anal sphincter and the urinary bladder is reproducible and is given the name 'ano-vesical' reflex. The reflex action was evoked by rapid anal inflation and not by the slow rate. It is likely that rapid inflation stimulates the anal stretch receptors, while slow inflation does not. Furthermore, as the anal inflation volume increases, the vesical pressure increases. This appears to be attributable to more stretch receptors being stimulated with the greater volume of anal inflation.

In paraplegic subjects, there was vesical pressure increase upon rapid anal inflation. However, the increase occurred only at an anal inflation volume higher than was used in the normal subjects. This may be related to a defect in the afferent sensations so that an increase of anal distension may be required to stimulate the reflex receptors.

\section{Role of ano-vesical reflex in micturition}

The explanation of how anal dilatation initiates micturition will be discussed in the light of the preceding studies. At defecation, the rectal detrusor contracts and the internal sphincter reflexly relaxes for the stools to pass. ${ }^{2.9}$ Reflex internal sphincter relaxation seems to evoke two reflexes: the ano-vesical reflex and the dilatation anal reflex. ${ }^{10}$ The former initiates vesical contraction while the latter induces contraction of both the external anal and urethral sphincters.

These two reflexes allow for the concomitant evacuation of both the rectal and vesical detrusor. Thus, if there is a desire to evacuate (both urine and stools), the external anal and urethral sphincters relax voluntarily. If conditions are inopportune for evacuation, the external anal and urethral sphincters continue contraction voluntarily. Their contraction inhibits internal sphincter relaxation which leads to 
reflex relaxation of the detrusor with adaptation to its contents and disappearance of the desire to evacuate. Voluntary external sphincter (anal or urethral) contraction to inhibit internal sphincter relaxation with a resulting detrusor relaxation is called 'the voluntary inhibition reflex'. ${ }^{11}$

If there is the desire to evacuate one detrusor, but not the other, the external sphincter of the detrusor concerned relaxes voluntarily, while the sphincter of the other detrusor remains voluntarily contracted. This is achieved by means of the selective individual sphincter action, ${ }^{12}$ which needs to be mentioned briefly. A previous study ${ }^{12}$ has shown that the two external sphincters, anal and urethral, arise from the puborectalis muscle. They are striated muscles which contract and relax voluntarily; furthermore, they share in reflex actions as in dilatation and closing anal reflexes. ${ }^{10}$ Each sphincter has a separate innervation from the pudendal nerve: the external anal from the inferior rectal and the external urethral from the perineal branch. The voluntary selective individual sphincter action depends on the separate innervation of each sphincter. For this reason, one sphincter could be voluntarily contracted or relaxed while the other is not; meanwhile both can reflexly contract or relax.

\section{Role of ano-vesical reflex in paraplegic patients}

Rapid anal dilatation induced increased vesical pressure in all the paraplegic patients examined. However, the pressure increase occurred at higher volumes of anal inflation than in normal subjects. Further, no correlation was found between the stimulus intensity (anal distension volume) and the vesical response.

In paraplegic patients, it is most likely that urination induced by digital anal dilatation occurs through the ano-vesical reflex. Anal dilatation appears to stimulate the internal sphincter stretch receptors and the impulses reach a spinal centre below the thoracic segments which are involved in paraplegic patients. In accord with other investigators, ${ }^{13.14}$ the spinal centre is believed to represent both the rectal and vesical detrusor. Impulses from the spinal centre would reach the vesical detrusor through the pelvic plexus, leading to vesical contraction and urination.

\section{Acknowledgement}

The author expresses his thanks to Mrs Margot Yehia who revised this manuscript.

\section{References}

1 Denny-Brown D, Robertson EG (1933) On the physiology of micturition. Brain 56: 149-184.

2 Denny-Brown D, Robertson EG (1935) An investigation of the nervous control of defecation. Brain 58 256-310.

3 Pedersen E. Harving H. Klemar B. Torring J (1978) Human anal reflexes. J Neurol Neurosurg Psychiatry 44: $813-818$.

4 Shafik A (1991) Constipation. Some provocative thoughts. J Clin Gastroenterol 13: 259-267.

5 Shafik A (1992) Micturition and urinary continence. New concepts. Int Urogynecol J 3: 168-175.

6 Fletcher TF, Bradley WF (1978) Neuroanatomy of the bladder-urethra. J Urol $119153-160$.

7 Bradley WF. Neural control of urethrovesical junction. Clin Obstet Gynaecol 21: 653-659.

8 Thuroff JW. Bazeed MA, Schmidt RA. Wiggin DM. Tanagho EA (1982) Functional pattern of sacral root stimulation in dogs. I Micturition. J Urol 127: 1031-1033.

9 Gowers WR (1877) The autonomic action of the sphincter ani. Proc $R$ Soc (London) 26: 77-84.

10 Shafik A (1991) Dilatation and closing anal reflexes. Description and clinical significance of new reflexes. Preliminary report. Acta Anat 142: 293-298.

11 Shafik A (1980) A new concept of the anatomy of the anal sphincter mechanism and the physiology of defecation. IX. The single loop continence: a new theory of the mechanism of anal continence. Dis Colon Rectum 23: 37-43.

12 Shafik A (1984) Pelvic double-sphincter control complex: theory of pelvic organ continence with clinical application. Urology 23: 611-618.

13 Petras JM. Cummings JF (1978) Sympathetic and parasympathetic innervation of urinary bladder and urethra. Brain Res 153: 363-368.

14 De Araujo CG, Schmidt RA. Tanagho EM (1982) Neural pathways to lower urinary tract identified by retrograde axonal transport of horseradish peroxidase. Urology 14: 290-295. 